\title{
Coping with Problems of Understanding in Interorganizational Relationships: Using Formalization as a Means to make Sense
}

\author{
Paul W.L. Vlaar, Frans A.J. Van den Bosch and Henk W. Volberda
}

\begin{tabular}{|l|l|}
\hline \multicolumn{2}{|l|}{ ERIM REPORT SERIES RESEARCH IN MANAGEMENT } \\
\hline ERIM Report Series reference number & ERS-2006-034-STR \\
\hline Publication & July 2006 \\
\hline Number of pages & 35 \\
\hline Persistent paper URL & \\
\hline Email address corresponding author & pvlaar@rsm.nl \\
\hline Address & Erasmus Research Institute of Management (ERIM) \\
& RSM Erasmus University / Erasmus School of Economics \\
& Erasmus Universiteit Rotterdam \\
& P.O.Box 1738 \\
& 3000 DR Rotterdam, The Netherlands \\
& Phone: + 31104081182 \\
& Fax: $\quad+31104089640$ \\
& Email: info@erim.eur.nl \\
& Internet: www.erim.eur.nl \\
\hline
\end{tabular}

Bibliographic data and classifications of all the ERIM reports are also available on the ERIM website: www.erim.eur.nl 


\section{ERASMUS RESEARCH INSTITUTE OF MANAGEMENT}

\section{REPORT SERIES \\ RESEARCH IN MANAGEMENT}

\begin{tabular}{|c|c|}
\hline \multicolumn{2}{|c|}{ ABSTRACT AND KEYWORDS } \\
\hline Abstract & $\begin{array}{l}\text { Research into the management of interorganizational relationships has hitherto primarily focused } \\
\text { on problems of coordination, control and to a lesser extent, legitimacy. In this article, we assert } \\
\text { that partners cooperating in such relationships are also confronted with 'problems of } \\
\text { understanding'. Such problems arise from differences between partners in terms of culture, } \\
\text { experience, structure and industry, and from the uncertainty and ambiguity that participants in } \\
\text { interorganizational relationships experience in early stages of collaboration. Building on Karl } \\
\text { Weick's theory of sensemaking, we advance that participants in interorganizational relationships } \\
\text { use formalization as a means to make sense of their partners, the interorganizational } \\
\text { relationships in which they are engaged and the contexts in which these are embedded so as to } \\
\text { diminish problems of understanding. We offer a systematic overview of the mechanisms through } \\
\text { which formalization facilitates sensemaking, including: (1) focusing participants' attention; (2) } \\
\text { provoking articulation, deliberation and reflection; (3) instigating and maintaining interaction; and } \\
\text { (4) reducing judgment errors and individual biases, and diminishing incompleteness and } \\
\text { inconsistency of cognitive representations. In this way, the article contributes to a better } \\
\text { understanding of the relationships between formalization and sensemaking in collaborative } \\
\text { relationships, and it carries Karl Weick's thinking on the relationship between sensemaking and } \\
\text { organizing forward in the context of interorganizational management. }\end{array}$ \\
\hline Free Keywords & Formalization, Sensemaking, Understanding, Interorganizational Cooperation \\
\hline Availability & $\begin{array}{l}\text { The ERIM Report Series is distributed through the following platforms: } \\
\text { Academic Repository at Erasmus University (DEAR), DEAR ERIM Series Portal } \\
\text { Social Science Research Network (SSRN), SSRN ERIM Series Webpage } \\
\text { Research Papers in Economics (REPEC), REPEC ERIM Series Webpage }\end{array}$ \\
\hline Classifications & $\begin{array}{l}\text { The electronic versions of the papers in the ERIM report Series contain bibliographic metadata } \\
\text { by the following classification systems: } \\
\text { Library of Congress Classification, (LCC) LCC Webpage } \\
\text { Journal of Economic Literature, (JEL), JEL Webpage } \\
\text { ACM Computing Classification System CCS Webpage } \\
\text { Inspec Classification scheme (ICS), ICS Webpage }\end{array}$ \\
\hline
\end{tabular}


Coping with Problems of Understanding in Interorganizational Relationships:

Using Formalization as a Means to make Sense

\author{
Paul W.L. Vlaar \\ Frans A.J. Van den Bosch \\ Henk W. Volberda
}

Dept. of Strategic Management and Business Environment

RSM Erasmus University

Erasmus University Rotterdam

P.O. Box 1738, 3000 DR Rotterdam, The Netherlands

Phone: +31 10408 9613/2005. E-mail: pvlaar@rsm.nl

www.strategyaterasmus.nl

\begin{tabular}{|c|}
\hline Final version: 31-05-2006 \\
Paper accepted for publication in special issue of Organization Studies \\
"Making Sense of Organizing: A Special Issue in Honor of Karl Weick“ \\
\hline
\end{tabular}

\title{
ACKNOWLEDGEMENTS
}

This research has benefited from inspiring discussions with Charles Baden-Fuller, Justin Jansen, and Rosalinde Klein Woolthuis. We are also grateful for the comments issued by attendees of the $65^{\text {th }}$ Academy of Management Conference and for the valuable suggestions provided by the editors and reviewers of the special issue in honour of Karl Weick of Organization Studies. The research has further profited from financial support of RSM Erasmus University Trust Fund and Erasmus Research Institute of Management (ERIM). All remaining errors are the responsibility of the authors. 


\title{
Coping with Problems of Understanding in Interorganizational Relationships:
}

\author{
Using Formalization as a Means to make Sense
}

\begin{abstract}
Research into the management of interorganizational relationships has hitherto primarily focused on problems of coordination, control and to a lesser extent, legitimacy. In this article, we assert that partners cooperating in such relationships are also confronted with 'problems of understanding'. Such problems arise from differences between partners in terms of culture, experience, structure and industry, and from the uncertainty and ambiguity that participants in interorganizational relationships experience in early stages of collaboration. Building on Karl Weick's theory of sensemaking, we advance that participants in interorganizational relationships use formalization as a means to make sense of their partners, the interorganizational relationships in which they are engaged and the contexts in which these are embedded so as to diminish problems of understanding. We offer a systematic overview of the mechanisms through which formalization facilitates sensemaking, including: (1) focusing participants' attention; (2) provoking articulation, deliberation and reflection; (3) instigating and maintaining interaction; and (4) reducing judgment errors and individual biases, and diminishing incompleteness and inconsistency of cognitive representations. In this way, the article contributes to a better understanding of the relationships between formalization and sensemaking in collaborative relationships, and it carries Karl Weick's thinking on the relationship between sensemaking and organizing forward in the context of interorganizational management.
\end{abstract}

Descriptors: Formalization, Sensemaking, Understanding, Interorganizational Cooperation 


\section{Introduction}

Interorganizational relationships, such as alliances, joint ventures and outsourcing initiatives, are known to entail issues of coordination, control and legitimacy (see Kale et al. 2001; Madhok 2002; Sitkin and Bies 1993). However, they also involve 'problems of understanding,' which emanate from the fact that participants in such relationships are accustomed to different structures, cultures, functional capabilities (Barkema and Vermeulen 1997; Doz 1996), cognitive frames (Nooteboom 1992), terminologies (Kaghan and Lounsbury 2006), and management styles and philosophies (Lane and Lubatkin 1998). Problems of understanding are aggravated, because cooperating parties come from disparate backgrounds, and work in different industries, with dissimilar belief systems (Sutcliffe and Huber 1998). Moreover, especially in the early stages of cooperation, interorganizational relationships are frequently characterized by relatively high levels of ambiguity and uncertainty (Carson et al. 2006). This leads participants in such relationships to develop distinct interpretations and understandings of the same phenomena (Porac et al. 2002; Vaara 2003) and it increases the likelihood that misinterpretations and misunderstandings occur (Shankarmahesh et al. 2004). More particularly, it confronts them with difficulties in understanding their partners, the relationships in which they are engaged and the contexts in which these are embedded.

Consequently, existing patterns of beliefs and assumptions may have to be revised, and cognitive reorientations (Fiss and Zajac 2006; Gioia and Chittipeddi 1991) and the creation of new, more coherent understandings become imperative for collective action (Maitlis 2005; Weick 1993). Sensemaking processes are therefore assumed to play a central role during collaborative efforts. These processes form 'the primary site where meanings materialize that inform and constrain' action (Weick et al. 2005: 409, citing Mills 2003: 35), and they permit 
parties with 'different views of the purposes and expectations of a relationship to achieve congruency’ (Ring and Van de Ven 1994: 99). Although sensemaking may develop through story-telling and other informal means of communication (Balogun and Johnson 2005; Kirsch 2004; Rouleau 2005), in the context of interorganizational relationships it has been shown to be intricately related to formal processes of negotiating and contracting as well (see Ariño and Ring 2004; Ring and Rands 1989; Ring and Van de Ven 1989 1994).

Considering formalization's relationship with sensemaking, we believe that formalization is not only the social product or sediment (Kaghan and Lounsbury 2006; Klein Woolthuis et al. 2005; Mayer and Argyres 2004; Putnam and Cooren 2004), but also a facilitator of sensemaking in interorganizational relationships, indicating a reciprocal relationship between both concepts (Ring and Van de Ven 1989 1994). We suggest that formalization may function as a means to make sense, enabling participants in collaborative relationships to cope with problems of understanding. This is supported by Blomqvist et al. (2005: 497), stating that 'the contracting process may be used purposefully to increase mutual understanding,' and by Kaghan and Lounsbury (2006: 3) who argue that formal written contracts provide a structure 'within which on-going relationships can proceed sensibly over time.' Blomqvist et al. (2005: 502), for example, found that a global machine and equipment supplier and a small metal engineering company 'got to know each other through the lengthy contracting process', indicating that this process enabled them to make sense of their partner. Although these studies suggest that formalization can be conducive to sensemaking, and to solving problems of understanding, a systematic overview of the mechanisms through which this occurs has hitherto been absent in the literature. In this article, we therefore address the following research question: How does formalization influence sensemaking, and eventually problems of understanding, in interorganizational relationships? 
Investigating this question warrants a proper definition of formalization. As with most concepts ending in '-tion', formalization is ambiguous with regard to processes and outcomes - 'between the way one gets there, and the result' (Baum and Rowley 2002: 1). It both refers to the process of codifying and enforcing inputs, outputs and behaviours (Ouchi 1979), and to the outcomes of this process in the form of contracts, rules and procedures (Hage and Aiken 1966). This distinction becomes obvious when one considers contractual planning - a principal form of formalization in interorganizational relationships. Contractual planning consists of the 'process of projecting exchanges into the future,' but it also eventuates in promises or obligations that are recorded in contracts, representing formalization as an outcome (Macneil 1980: 4). We consider both forms of formalization here, as we presume that the formalization process inevitably leads to formal documents, and because we believe that formalization 'accomplishes part of its purpose not just with the words agreed upon,' but also by means of the process through which parties arrive at these words and through the 'words discussed and ultimately rejected' (Hill 2001: 56). Our ontological view of formalization thus covers contracts, rules and procedures (formalization as nouns, entities or things), as well as processes of codification and enforcement (formalization as an organizing process), which renders our approach to investigating the relationship between formalization and sensemaking necessarily pluralistic in nature (see Van de Ven and Poole 2005).

We further investigate our research question by building upon Karl Weick's work on sensemaking and organizing (Weick 196919791995 2001; Weick et al. 2005), and by critically examining research on interorganizational structuring practices (e.g. Ariño and Ring 2004; Ring and Rands 1989; Ring and Van de Ven 1989 1994). In doing so, we focus on the relationships between formalization, sensemaking, understanding and the mechanisms through which formalization facilitates sensemaking, including: (1) focusing attention; (2) 
forcing articulation, deliberation and reflection; (3) instigating and maintaining interaction; and (4) reducing judgment errors and individual biases, and diminishing incompleteness and inconsistency of cognitive representations (see Figure 1). We argue that problems of understanding propel the need for formalization, which subsequently influences sensemaking through four mechanisms, eventually enabling participants in interorganizational relationships to achieve more congruent understandings.

Insert Figure 1 about here

The article provides two contributions. First, it elucidates that interorganizational relationships not only entail issues of coordination, control and legitimacy, but also problems of understanding, resulting from the differences between cooperating parties and from the ambiguity and uncertainty that tend to prevail in the early stages of interorganizational cooperation. This description of cooperative endeavours conforms to Karl Weick's accounts of complex, ambiguous events, and it complements more conventional perspectives on interorganizational governance prevailing in the literature (e.g. see Kale et al. 2001; Madhok 2002) by challenging the assumption that participants in these relationships have clear images of their partners, the relationships in which they are engaged and the contexts in which these are embedded (Jap 2001). Second, the article carries Karl Weick’s (1969 19791995 2001; see also Weick et al. 2005) work on the relationship between organizing and sensemaking forward in the context of interorganizational relationships. We capitalize on Weick's contributions in this area to develop a richer and more comprehensive notion of the relationship between formalization, sensemaking, and problems of understanding than has hitherto been available in the literature on interorganizational relationships. In particular, we present a systematic overview of the mechanisms through which formalization contributes to 
sensemaking, offering researchers a fertile basis for further theorizing in this area, and helping practitioners to address problems of understanding in their collaborative endeavours.

The article is organized accordingly. First, we briefly discuss problems of understanding in interorganizational relationships. Subsequently, we elaborate on four mechanisms through which formalization may facilitate sensemaking, and help participants in interorganziational relationships to cope with these problems. We conclude with the major implications of our study and promising avenues for future research.

\section{Problems of Understanding in Interorganizational Relationships}

Discontinuities in structures, contexts, routines, expectations and perceptual frameworks (Hoang and Rothaermel 2005; Rouleau 2005; Weick 1995; Zollo et al. 2002) cause problems of understanding in interorganizational relationships, particularly in early stages of collaboration. They lead participants to interpret and understand the same phenomena differently (Porac et al. 2002; Sutcliffe and Huber 1998; Vaara 2003). Such problems are especially pertinent in relationships between unfamiliar partners (Ring and Van de Ven 1994; Sutcliffe and McNamara 2001) and in complex, cross-sector collaborations, where 'the nature of the pie, its size, and an assessment of its ingredients may be ambiguous' (Jap 2001: 86). In these cases, cooperation brings into tension 'extraordinarily complex ways of framing problems, as well as divergent knowledge and truth claims based on competing disciplinary paradigms’ (Couchman and Fulop 2002: 43).

Consequently, participants may not fully comprehend each other's competencies, strengths and weaknesses, and they may find it hard to envision the projected outcomes of relationships (Jap 2001; Jap and Ganesan 2000). Furthermore, they may experience difficulties in 
appreciating the potential for transacting with each other (Ariño and Ring 2004) due to an absence of unity in purpose and expectations (Mjoen and Tallman 1997). Problems of understanding also tend to prevail when collaborative relationships are embedded in risky, uncertain settings, and when they involve non-standard business objectives (Jap 2001; McGinn and Keros 2002). In these cases, ambiguity and uncertainty become fundamental concerns (Carson et al. 2006), constraining the extent to which participants in interorganizational relationships understand their partners and the new contexts in which they have to act (Meindl et al. 1996; Ring 2000). In such cases, common or congruent understandings have to be developed to enable cooperation and joint value creation (Balogun and Johnson 2004; Weick 2001; White and Lui 2005). Participants attempt to ameliorate their understandings by making sense of their partner, the relationships in which they are engaged and the contexts in which these are embedded (Kirsch 2004; Lindenberg 2003; McGinn and Keros 2002; Ring 2000).

Sensemaking, a concept that is central to the work of Karl Weick (e.g. 196919791995 2001), refers to the reciprocal interaction of information seeking, meaning ascription and action (Thomas et al. 1993). In the context of this paper, it concerns the interactive processes by which participants in interorganizational relationships construct accounts that allow them to comprehend the world and act collectively (Maitlis 2005; Rouleau 2005; Weick and Roberts 1993). It derives from the needs of individuals to have a sense of self-identity in relation to others and to construct a common factual order regarding their social relationships (Turner 1987). Sensemaking not only concerns identifying, assimilating and utilizing information, but also removing its equivocality (Weick 1995), and diminishing participants’ cognitive disorder by foreclosing alternative interpretations and understandings of phenomena (McKinley and Scherer 2000), so that the world appears more stable and enduring (Weick 1995). 


\section{Formalization as a Means to Make Sense}

To elucidate how formalization affects sensemaking, we first illuminate Weick's position on the relationship between sensemaking and organizing. Although Weick (1995: 229) contends that 'a little order can go a long way', he also acknowledges that some kind of structure needs to be present to guide action, and to direct attention to particular aspects of a situation (Weick 1995). He further posits that 'sensemaking and organization constitute one another' and that sensemaking involves the 'continued redrafting of an emerging story so that it becomes more comprehensive, incorporates more of the observed data, and is more resilient in the face of criticism' (Weick et al. 2005: 410-411, 415), which conforms to descriptions of negotiation and contracting processes in interorganizational relationships (e.g. see Mayer and Argyres 2004). Weick (2001: 116) also asserts that 'a framework of roles, rules, procedures, configured activities and authority relations' can both reflect and facilitate meanings and that organizing may help to establish a workable level of uncertainty and ambiguity (Weick 1969 1979), which corresponds to images of formalization as a means to reduce and absorb complexity and ambiguity (Carson et al. 2006).

Weick thus acknowledges that organizing processes, such as formalization, may be conducive to sensemaking. Building on his insights, we further develop the idea that formalization enables, or even forces collaborating parties to engage in sensemaking, helping them to create common ground and achieve mutual understanding (Blomqvist et al. 2005; McGinn and Keros 2002; Ring and Van de Ven 1989 1994). As became evident from three alliances in the Norwegian retailing industry, formal aspects to a large extent anchor, inform, influence and add to the informal and implicit understanding of cooperating parties (Ness 2002: 31), and they assist parties in defining and redefining 'the terms of their interdependence' (Walton and McKersie 1965: 35, as cited in Putnam 2003). Although this 
suggests that formalization influences sensemaking, and eventually the creation of generic understandings that form a basis for interorganizational exchange (Ariño and Ring 2004; McGinn and Keros 2002; Sivadas and Dwyer 2000), a systematic overview of the mechanisms through which this may occur is still lacking in the literature. In this article, we develop such an overview (see Figure 1), by discussing four mechanisms that feature prominently in Karl Weick's work on sensemaking and in literature on formalization, thereby constituting the most important points of contact between both concepts.

\section{Focusing Attention}

A first mechanism through which formalization enables sensemaking is labelled focusing attention. Participants in interorganizational relationships generally display a joint focus or co-orientation on formal documents and processes, which renders formalization a focusing device (Avadikyan et al. 2001; Nooteboom 1992; Sutcliffe and McNamara 2001; Taylor and Robichaud 2004; Yu et al. 2005). Formal documents and processes serve as focal points for different streams of ongoing activity, providing them with meaning and direction (Weick 2001; Yakura 2002). They focus attention by clarifying whether there are decisions that need to be made and what those decisions might consist of (Weick 2001), and by demarcating what is allowed, expected, acceptable and possible, and what is not (Carson et al. 2006; Lui and Ngo 2004; Nellore 2001). Formalization helps to selectively highlight some issues and marginalize or omit others (Brown 2000; Fiss and Zajac 2006), and it prevents participants from being distracted by issues of secondary importance (Delmar and Shane 2003). Formal items on agenda meetings, for example, enable partners to open up discussions on specific issues, and close off discussion on other topics (Putnam 2003), so that participants can focus on a small number of concerns and expend their cognitive efforts on restricted problem areas, reducing the cognitive complexity they experience (Boisot and Child 1999; Campbell 1988). 
Mayer and Argyres (2004: 400) offer an example of formalization's role in focusing attention in their description of a relationship between a Silicon Valley Software firm and a Japanese electronics producer. They note that formal statements of work 'forced the parties to determine mutually agreeable delivery dates early in the coding process, before managerial attention on scheduling was lost.' Similarly, Avadikyan et al. (2001: 1453) describe how a contract for the development of a fuel cell powered electric car influenced 'the methodological orientations' of the participants in this relationship. These examples show that formalization provides the 'general direction as to how the parties to a contract should orient their mutual interaction so as to achieve a common purpose' (Kaghan and Lounsbury 2005: 12). The resulting focus in attention may not only reduce the complexity perceived by partners (Boisot and Child 1999), but it may also enable the absorption of complexity during relationships, provided that participants remain open and willing to revise formal documents continuously (Ring 2000), maintain contingencies and preserve flexibility. In such cases, formalization becomes a process by which reality is constructed and reconstructed, instead of a means by which reality is fixed at one point in time. Formalization then restricts the extent to which participants intrude their environment and acquire and perceive cues and connections around which they cohere and structure their beliefs. It conditions sensemaking by limiting the information and cues on which participants focus their attention (Anand and Peterson 2000; Daft and Weick 1984). Summarizing, we argue that formalization entails a focus of attention, which subsequently influences sensemaking (see Figure 1).

Proposition 1: Formalization helps participants in interorganizational relationships to focus their attention, thereby affecting their ability to make sense of their partners, the relationships in which they are engaged and the collaborative contexts in which these are embedded. 


\section{Forcing Articulation, Deliberation and Reflection}

A second mechanism through which formalization facilitates sensemaking concerns articulation, deliberation and reflection. Formalization forces parties 'to articulate their individual and mutual goals explicitly during the contracting process' (Blomqvist et al. 2005: 501). It thereby enables participants to lift equivocal knowledge out of the tacit, private, complex, random and past to make it explicit, simpler, ordered and relevant to the situation at hand (Obstfeld 2004). By doing so, formalization not only generates more 'raw material' from which cooperating parties can make sense (Daft and Weick 1984; Thomas and Trevino 1993), but it also assists in clarifying their identity, positions and payoffs, and the behaviour and interaction that they prefer, so that interpretable responses by other participants are elicited (Hill and Levenhagen 1995; Shankarmahesh et al. 2004). Formalization thus ensures 'that the structural foundations of a deal are well articulated' (Kaghan and Lounsbury 2005: 21). On an individual level, such articulation is associated with synthesizing issues on paper, forcing people to reflect, cogitate, and think deeper (Weick 1995; Zollo and Winter 2002; Zollo and Singh 2004). It stimulates participants to deliberate beyond general understandings, and to be clear about the variables and parameters that need to be considered, the sequence or priority with which different criteria of decision-making are to be invoked, and the process of inference by which decisions are to be made (Katz and Kahn 1966). This is reinforced by the fact that participants wish to avoid unnecessary grievances and mistakes. They therefore give contracts, rules and procedures generally 'more deliberation than orders' and try to make sure that they are ‘carefully expressed’ (Gouldner 1954: 162; see also Putnam 2003).

An example of formalization's role in provoking articulation, deliberation and reflection concerns negotiation and contracting efforts in an alliance between Xerox and Fuji Xerox. The Xerox executive for this alliance claimed that the negotiating teams left no stone 
unturned. He mentioned that 'a lot of bright people argued down all the alleys looking for potential future problems,' and that they spent their time 'going through all the "what if" questions.' They continuously 'took the agreement apart and put it back together' (GomesCasseres 1996: 27). Another example consists of a relationship between a Silicon Valley Software firm and a Japanese electronics producer in which a 'risk and concern' section was inserted in formal statements of work in order to 'force the participants to think through the project' (Mayer and Argyres 2004: 400). In contrast, a lack of formalization may inhibit deliberation and reflection, witnessing a relationship between Coca-Cola and Nestlé. When negotiating the deal, 'too little attention was paid to the alliance business plan. Market pressures were such that executives rushed into the collaborative agreement [...]. The contract was signed in one weekend' (Ariño and Reuer 2004: 45). In this case, a lack of formalization resulted in low degrees of deliberation and reflection and the relationship was dissolved after three years, despite a stipulated contract horizon of one hundred years. Through forcing articulation, deliberation, and reflection, formalization turns circumstances into words and salient categories that form a basis for sensemaking (Weick et al. 2005). Moreover, it renders sensemaking processes more active and animated, and imbues them with social energy (see Maitlis 2005). Participants become more heedful (see Weick 1993), question current assumptions, beliefs and understandings, and actively construct their new reality. To recapitulate, we argue that formalization facilitates articulation, deliberation, and reflection, and thereby influences sensemaking (see Figure 1).

Proposition 2: Formalization helps participants in interorganizational relationships to articulate, deliberate and reflect upon issues, thereby affecting their ability to make sense of their partners, the relationships in which they are engaged and the collaborative contexts in which these are embedded. 


\section{Instigating and Maintaining Interaction}

A third mechanism through which formalization facilitates sensemaking revolves around its role in instigating and maintaining interaction (Avadikyan 2001; Balogun and Johnson 2005; Simons 1995). Interaction between participants in interorganizational relationships flows through 'series of formal processes' and outcomes (Ring 2000: 154), which serve as frameworks, mediums, or triggers for interaction (Ness 2002; Putnam 2003). Formalization is used to spin new stories; set actions in motion; announce beginnings, milestones, and ends; and trigger changes of course (Avadikyan 2001; Eccles and Nohria 1992; Weick 1995). It entails the exchange of proposals between parties, which mediate conversations and dialogues (Nellore 2001; Putnam 2003) and enable parties to discuss tasks not yet executed and outcomes that still have to be created (Yakura 2002). Formalization involves processes of arguing, listening and working to reconcile differences (see Weick 2004; Weick and Roberts 1993), enabling individuals to 'express their opinions and beliefs, engage in constructive confrontations, and challenge each other's viewpoints' (Zollo and Winter 2002: 341). In this way, participants in collaborative relationships come to share and synthesize knowledge sets, implicit assumptions and mental models (Kotabe et al. 2003).

An example of formalization's role in instigating and maintaining interaction concerns a geographically and organizationally dispersed group of artificial intelligence language designers, which treated each release of a formal manual 'as an event initiating discussion of perceived gaps or problems and further proposals and agreements, which in turn led to the next draft' (Orlikowski and Yates 2002: 692). Another example concerns two partnerships involving original-equipment manufacturers in the auto and aircraft industries, where contracts provided a setting for discussion, allowing partners to 'understand the specifications, each other's capabilities, and the resources needed to do the job' (Nellore 
2001: 502). These examples indicate that formalization entails representations of reality through which participants in interorganizational relationships interrelate and make sense of their new situation. Summarizing, we contend that formalization helps to instigate and maintain interaction among participants in interorganizational relationships, thereby offering fertile ground for sensemaking (see Figure 1).

Proposition 3: Formalization instigates and maintains interaction among participants in interorganizational relationships, and thereby affects their ability to make sense of their partners, the relationships in which they are engaged and the collaborative contexts in which these are embedded.

\section{Reducing Biases, Judgment Errors, Incompleteness and Inconsistency}

Finally, we advance that formalization facilitates sensemaking by reducing the impact of individual biases and judgment errors, and by augmenting the completeness and consistency of participants' cognitive representations of their partners, the relationships in which they are engaged and the contexts in which these are embedded. Formalization reduces influences of individual biases and judgment errors on collaboration as it is sensitive to the ideas and interests of several persons. It compensates for deficiencies in individual thought processes, such as global and undifferentiated thinking, cognitive nearsightedness and oversimplified notions of causation (Katz and Kahn 1966; Ketokivi and Catañer 2004). It therefore tends to result in more nuanced, consummate and consistent pictures of reality (Katz and Kahn 1966), increasing the reliability and predictability of decision making processes and outcomes (Sutcliffe and McNamara 2001). This is reinforced by the fact that formalization requires parties to adopt relatively unambiguous proxies for desired behaviour and outcomes so that deviations are clearly verifiable (Carson et al. 2006). 
Formalization also raises the likelihood that relevant information is considered and treated properly, and that inconsistencies are uncovered and eliminated (Avadikyan et al. 2001; Sutcliffe and McNamara 2001). An example stems from an alliance between L’Oréal and Esthetique, in which additions to the contractual framework 'reduced "noise" in the interaction on all levels, as typically small and recurring conflicts were dealt with once and for all' (Ness 2002: 25). An example of a contrasting situation is offered by Doz (1996). In his description of an alliance between Ciba Geigy and Alza aimed at the development of controlled oral pills and transdermal patches, he indicates that low levels of formalization made 'that the initial agreement left room for [...] widely different perceptions and broad frames [which] led to growing suspicions and tensions as each party was searching for clues in the behaviour of the other' (Doz 1996: 68). These examples indicate that formalization may enable participants in interorganizational relationships to make sense of their new situation by reducing the impact of biases and judgment errors and by increasing the consistency and completeness of cognitive representations. This is captured in a fourth proposition (see Figure 1).

Proposition 4: Formalization reduces the impact of individual biases and judgment errors, and it diminishes incompleteness and inconsistencies among the cognitive representations held by participants in interorganizational relationships, thereby affecting their ability to make sense of their partners, the relationships in which they are engaged and the collaborative contexts in which these are embedded.

\section{Towards a Balanced View}

In previous paragraphs, we argued that formalization facilitates sensemaking through four mechanisms, possibly turning ambiguous or equivocal circumstances into a situation that is 
‘comprehended explicitly in words and that serves as a springboard into action' (Weick et al. 2005: 409, citing Taylor and Van Every 2000: 40). Formalization assists participants in testing and establishing expectations as to how roles and responsibilities are divided, how partners are doing and how they will react to what one says and does (Hill and King 2004; Klein Woolthuis et al. 2005; Narayandas and Rangan 2004; Sivadas and Dwyer 2000; Weick and Roberts 1993), and it enables them to assess and appreciate the nature and purpose of relationships (Ring and Van de Ven 1994). Formalization further helps participants to discover the amount of agreement they have on cause-effect linkages and on priorities and preferences for outcomes, which coincides with a description of sensemaking in early stages by Weick and McDaniel (1989). Formalization may thus help participants to make sense of their partners, the relationships in which they are engaged and the contexts in which these are embedded, by offering them 'a collaborative framework in which the potential for joint action is both significant and beneficial' (Hardy et al. 2005: 63).

However, we recognize that formalization may also have negative effects on sensemaking, as it may make events seem more comprehensible and controllable than they really are (Brown 2004) fuelling the illusion that 'management' or 'control' are in place (Brown 2000; Yakura 2002). Furthermore, high degrees of formalization may result in psychic imprisonment (Snell 2002), so that subsequent sensemaking activities proceed within overly narrow analytical and decision-making boundaries (Ring 2000). In such cases, formalization leads to a focus of attention that is too rigid or inappropriate, which may lead managers to ignore or overlook critical factors, and render their understandings too parsimonious, myopic or otherwise incongruent with reality (Hill and Levenhagen 1995; Sutcliffe and McNamara 2001). In this respect, Weick (2001: 460) mentions that 'once a sense of the situation begins to develop, that sense can be terribly seductive and can resist updating and revision.' It may also lead 
managers to lose 'sight of the forest' while picking away 'at the branches and leaves of the trees' (Putnam 2003: 48). This was evident in Doz's (1996: 68) description of an alliance between Ciba Geigy and Alza, where sensemaking led to cognitive understandings that 'made the behavioural learning agenda look taller and taller.'

Formalization has other disadvantages in that it can easily turn into formalism (Mintzberg 1994), cause rigidity and a loss of creativity and flexibility (Volberda 1998), and diminish trust (Klein Woolthuis et al. 2005). Moreover, attempts to articulate, deliberate and reflect upon issues may entail high costs and efforts, and they can even hamper interaction if their benefits are unclear to participants in collaborative endeavours. Furthermore, formalization may not only diminish but also introduce biases and errors, if it inappropriately reflects desired outcomes and behaviours. We acknowledge the fact that formalization has a dark side, and that it can generate undesired and unanticipated outcomes (Balogun and Johnson 2005; Yu et al. 2005). Or, as Mintzberg (1994: 386) notes 'formalization is a double-edged sword, easily reaching the point where help becomes hindrance.' We therefore conclude that the relationship between formalization and sensemaking is likely to be a curvilinear one, in which formalization contributes to sensemaking up to a certain point through each of the four mechanisms that we distinguished previously, after which it diminishes participants' capacity for sensemaking (see Figure 1).

Proposition 5: The extent to which formalization enables participants to: (1) focus their attention; (2) articulate, deliberate and reflect; (3) interact; and (4) reduce judgment errors and biases, and incompleteness and inconsistency of cognitive representations has a curvilinear relationship with their ability to make sense of their partners, the relationships in which they are engaged and the contexts in which these are embedded. 
Finally, we propose that formalization may help to solve problems of understanding by facilitating sensemaking in interorganizational relationships. Formalization is one way of organizing by which people make sense of equivocal inputs, which they enact back into their world to make it more orderly (Weick et al. 2005). It may thereby eventuate in more refined understandings of partners' cultures, management systems, capabilities and weaknesses, and offer participants more clarity about the context in which relationships are embedded (Zollo et al. 2002). Formalization may affect sensemaking in such a way that participants in interorganizational relationships create 'a solid understanding of the business, share a common fact base, and agree on important assumptions' (Kaplan and Beinhocker 2003: 72). They may gradually come to understand the nature of the pie that can be created in their relationship, the size of that pie, and the processes and resources that could help create the pie (Jap 2001). Moreover, they can improve their understanding of each other's intentions, actions and behaviour (Aulakh and Madhok 2002). The resulting collective consciousness (Clegg et al. 2002; Hill 2001), common reality, or shared understandings (Brown 2004; Hardy et al. 2005; Putnam and Cooren 2004) offer them a unitary basis for action (Maitlis 2005; Weick and Roberts 1993).

This does not imply that partners need to have the same point of view, or understand each other completely. Plurivocal interpretations and understandings will always persist among organizational actors due, among other reasons, to lasting differences in prior experience (see Balogun and Johnson 2004; Brown 2000 2004), and differences in interests and objectives. However, formalization's effects on sensemaking at least increase the likelihood that participants in interorganizational relationships develop mutual understandings next to their private understandings, which may enable coordinated action, while preserving the complexity of multiple individual cognitive structures (Barr and Huff 1997; Elsbach et al. 
2005; Weick 1995; Weick and Roberts 1993). Concluding, we advance that formalization affects sensemaking processes, which subsequently influence problems of understanding among participants in interorganizational relationships (see Figure 1).

Proposition 6: Through enabling participants in interorganizational relationships to make sense of their partners, the relationships in which they are engaged and the contexts in which these are embedded, formalization reduces the degree to which participants in interorganizational relationships experience problems of understanding.

\section{Discussion}

In this article, we have exemplified how formalization may help participants in interorganizational relationships to cope with problems of understanding. We have shown that formalization entails socio-psychological processes through which participants socially construct or 'enact' their realities (Ariño and Ring 2004; Vaara 2003; Weick 1995) and reduce the cognitive disorder, ambiguity and uncertainty that they experience (Carson et al. 2006; McKinley and Scherer 2000; Weick 197919952001 2004). Collectively, our arguments depict formalization as a process of 'constructive clarification' (Cardinal et al. 2004: 422) by which particular versions of reality are created, clarified, sustained and modified (Brown 2004), and as a form of structuring that generates and recreates meanings (Ranson et al. 1980). Our description accommodates several distinguishing features of sensemaking such as 'its genesis in disruptive ambiguity [e.g. the initiation of a new relationship], its beginnings in acts of noticing and bracketing [e.g. codification], its mixture of retrospect and prospect [e.g. different experiences of partners combined with converging understandings], [and] its culmination in articulation that shades into acting' [formalization as a basis for action] (Weick et al. 2005: 413). Our discussion strongly resembles notions of 
sensemaking as a 'guided and controlled' process, which results in the creation of more unitary and rich accounts of reality, that provide ‘common foundations for action' and enable 'the emergence of series of actions with a consistent focus’ (Maitlis 2005: 28).

It is important to note here that sensemaking efforts are undertaken in concert with sensegiving efforts, so as to 'influence the sensemaking and meaning construction of others' (Gioia and Chittipeddi 1991: 442). Although sensemaking is essentially a cognitive concept, while sensegiving also refers to communication (Shankarmahesh et al. 2004), both concepts are associated with the management of meaning (Maitlis 2005) and with continuous processes of organizing (Weick et al. 2005). Sensegiving efforts by some participants give rise to sensemaking efforts by others, which renders them interactional complements (Gioia and Chittipeddi 1991; Rouleau 2005). Although we focused on the influence of formalization on sensemaking in this paper, formalization may equally well serve sensegiving, assisting participants in framing and disseminating issues to stakeholders in their relationships (Fiss and Zajac 2006), and enabling them to provide descriptions and explanations, and create opportunities for interaction that help others to make sense (Maitlis 2005; Weick 1995).

\section{Theoretical and Practical Implications}

This article advances prior research on the sensemaking function of formalization (Ring and Van de Ven 1989 1994) by discerning the mechanisms through which formalization facilitates the creation of more congruent understandings among participants in interorganizational relationships. It indicates that researchers may benefit from embracing the inherent qualities of the process of formalization itself, instead of focusing on contracts, rules and procedures alone, something which is congruent with pleas by Weick and other researchers for more research into structuring processes (see Ariño and De la Torre 1998; 
Carson et al. 2006; De Rond and Bouchikhi 2004; Narayandas and Rangan 2004; Ring and Van de Ven 1994; Weick 2001; Weick et al. 2005). Moreover, our conceptualization of formalization implies that researchers should regard formalization as a means to achieve coordination, control, and legitimacy, but also as a means to cope with problems of understanding in interorganizational relationships. This implies that researchers may have to redirect their attention from coercive towards enabling types of formalization (see Adler and Borys 1996; Zollo and Winter 2002) in which higher levels of understanding (Zollo and Singh 2004) and the constitution of meaning (Giddens 1984) assume a more central position. Furthermore, premises of power, self-interest, and opportunism (Williamson 1985) seem to be insignificant when discussing formalization's role in coping with problems of understanding. Nevertheless, the creation of new understandings is not free of power issues and self-interested behaviour (Brown 2000 2004). Parties will, for example, attempt to influence and shape each other's beliefs in the direction that they prefer, and they frequently interpret phenomena with these interests in mind. Moreover, they may choose not to give other parties particular information for strategic reasons, or use their power to influence the issues that are captured in formal documents. This implies that formalization has to be regarded as ambivalent, in the sense that it is a vehicle of several functions (Avadikyan 2001; Madhok 2002), something which renders either-or discussions on formalization’s functioning unproductive (Klein Woolthuis et al. 2005).

Practitioners could use the insights generated in this article to establish more congruent understandings among participants in the relationships in which they are involved. This will prove to be particularly useful when their relationships are characterized by large interpartner differences and high degrees of ambiguity and uncertainty. In such cases, simply exchanging more information may not solve the problems that they experience, and efforts 
have to be put into shaping interpretations and understandings (Sutcliffe and Weber 2003; Thomas and Trevino 1993). This article has shown that formalization may be an important means for doing so. More specifically, the article offers practitioners insights into how formalization facilitates sensemaking, and how it helps to develop more congruent understanding in collaborative relationships.

\section{Future Research}

Opportunities for future research are abundant. First, researchers could investigate how power, politics, and resource and information asymmetries affect sensegiving and sensemaking in collaborative relationships. Such factors provide different people with unequal positions to influence the social construction of reality (Mills 2003). They affect, among other aspects, the extent to which parties have control over cues, communicate with each other and support or constrain each other's actions and behaviour (Weick et al. 2005). Moreover, when resource and information asymmetry exists between partners, participants are likely to perceive different cues and attribute different meanings to similar observations. After all, people interpret cues in light of their expectations and knowledge (Weick 1995). Power, politics, and resource and information asymmetries thus exert fundamental influences over sensegiving and sensemaking processes, rendering them important areas for future research.

Second, researchers could inquire into the relationship between formalization, understanding, and its other functions. Hitherto, it has remained unclear how better understandings of partners in interorganizational relationships affect coordination, control, and legitimacy. Several indications exist that these functions presuppose sensemaking. We know, for example, that sensemaking processes contribute to envisioning how value can be created 
(Ariño and Ring 2004), and that they assist in removing misunderstandings, information asymmetry and opportunities for moral hazard and opportunistic behaviour. We also know that these processes could lead to more accurate appreciations of the risks involved in a transaction, which should result in the design of more appropriate governance structures (Ring and Rands 1989; Ring and van de Ven 1989 1994), and which enables parties to develop a solid basis for their relationships, while tempering hubris and faddishness (Sampson 2003). However, a systematic overview of the relationship between formalization, understanding, and its other functions is not yet available. Related to this, researchers could attempt to develop a parsimonious yet comprehensive conceptual framework that allows for more systematic comparisons of the functions and dysfunctions, and eventually the performance effects of formalization across studies and contexts than currently presented in the literature (see White and Lui, 2005). A dialectic perspective in which the functions and dysfunctions of formalization are considered simultaneously could be a promising area for further investigation here (De Rond and Bouchikhi 2004).

A third option for future research concerns inquiries into organization, context and task characteristics that determine how the need for sensemaking evolves. We have presumed that the sensemaking function of formalization is particularly valuable for interorganizational relationships between partners possessing divergent skills, backgrounds and organizational structures, and for organizations based in disparate cultures or industries, as these differences can lead to misunderstandings and conflicts (Child and Rodrigues 2003). However, as partners get to know each other better and information asymmetries are being reduced, the need for sensemaking diminishes (Heide 2003), and issues become more clear-cut (see Koza and Lewin 1998; Rothaermel and Deeds 2004). Parties may have developed joint understandings that allow for uniquely efficient communication in the form of idiosyncratic 
interaction routines (Hoang and Rothaermel 2005; Kotabe et al. 2003; Zollo et al. 2002) and they may have come to know more about each other's structure, operations and competencies (Shenkar and Zeira 1992). Ring and Van de Ven (1994) therefore conclude that, in general, once the details of a cooperative relationship are established, sensemaking processes tend to be less intense than those that occur during transactional phases, at least until problems arise. This suggests that it is both worthwhile to investigate when the sensemaking function of formalization is most pertinent, and how it evolves over time.

A final avenue for future research pertains to investigating other means that facilitate sensemaking, such as informal processes of interaction (Balogun and Johnson 2005), and examining the factors that influence managers' preferences for each of them. An example of such a factor could be the likelihood that relationships experience negative effects of employee turnover (Ring and Van de Ven 1994). The departure of two founding fathers in a joint venture in the consumer products industry between a North-American and a French company illustrates our point. Ariño and De la Torre (1998: 321) explain that 'agreements and understandings that may have been implicit in their thinking, or that could have been articulated in an informal telephone call, [were] now easily misinterpreted by those not involved in the original design and negotiations.' In this case, formalization could have prevented knowledge dissipation and facilitated continued sensemaking and learning.

Concluding, the article contributes to research on organizing and sensemaking by discussing how formalization may help participants in interorganizational relationships to cope with problems of understanding. By doing so, it carries Karl Weick's thinking on sensemaking forward in the context of interorganizational management, and it offers a fertile basis for further theorizing in this field. 


\section{References}

Adler, Paul S., and Bryan Borys

1996 'Two types of bureaucracy: Enabling and coercive'. Administration Science Quarterly 41: 61-89.

Anand, Narasimhan, and Richard A. Peterson

2000 'When market information constitutes fields: Sensemaking of markets in the commercial music industry’ Organization Science 11/3: 270-284.

Ariño, Africa M., and Jose De la Torre

1998 'Learning from failure: Towards an evolutionary model of collaborative ventures'. Organization Science 9/3: 306-325.

Ariño, Africa M., and Jeff J. Reuer

2004 'Designing and renegotiating strategic alliance contracts'. Academy of Management Executive 18/3: 37.

Ariño, Africa M., and Peter Smith Ring

2004 'The role of justice theory in explaining alliance negotiations'. Working Paper No. 534 IESE Business School.

Aulakh, Preet S., and Anoop Madhok

2002 'Cooperation and performance in international alliances: The critical role of flexibility' in Cooperative Strategies and Alliances. F.J. Contractor, and P. Lorange (eds), 25-48. Boston: Elsevier.

Avadikyan, Arman, Patrick Llerena, Mireille Matt, Anne Rozan, and Sandrine Wolff 2001 'Organisational rules, codification and knowledge creation in inter-organisation cooperative agreements’. Research Policy 30: 1443-1458.

Balogun, Julia, and Gerry Johnson

2004 'Organizational restructuring and middle manager sensemaking'. Academy of Management Journal 47: 523-549.

Balogun, Julia, and Gerry Johnson 2005 'From intended strategies to unintended outcomes: The impact of change recipient sensemaking'. Organization Studies 26/11: 1573-1601.

Barkema, Harry G., and Freek Vermeulen

1997 'What differences in the cultural backgrounds of partners are detrimental for international joint ventures’. Journal of International Business Studies 28: 845-864.

Barr, Pamela S., and Anne S. Huff

1997 'seeing isn't believing: Understanding diversity in the timing of strategic response'. Journal of Management 34/3: 337-370.

Baum, Joel A.C., and Tim J. Rowley

2002 'Companion to organizations: An introduction' in The Blackwell Companion to Organizations. J.A.C. Baum (ed), 1-34. Oxford: Blackwell. 
Blomqvist, Kirsimarja, Pia Hurmellina, and Risto Seppänen

2005 'Playing the collaboration game right - balancing trust and contracting'. Technovation 25: 497-504.

Boisot, Max, and John Child

1999 'Organizations as adaptive systems in complex environments: The case of China'. Organization Science 10/3: 237-252.

Brown, Andrew D.

2000 'Making sense of inquiry sensemaking'. Journal of Management Studies 37/1: 45-75.

Brown, Andrew D.

2004 'Authoritative sensemaking in a public inquiry report'. Organization Studies 25/1: 95112.

Campbell, Donald J.

1988 'Task complexity: A review and analysis'. Academy of Management Review 13: 40-52.

Cardinal, Laura B., Sim B. Sitkin, and Chris Long

2004 'Balancing and rebalancing in the creation and evolution of organizational control'. Organization Science 15: 411-431.

Carson, Stephen J., Anoop Madhok, and Tao Wu

2006 'Uncertainty, opportunism and governance: The effects of volatility and ambiguity on formal and relational contracting'. Forthcoming in Academy of Management Journal.

Child, John, and Suzana B. Rodrigues

2003 'Corporate governance and new organizational forms: Issues of double and multiple agency’. Journal of Management and Governance 7: 337-360.

Clegg, Stewart R., Tyrone S. Pitsis, Thekla Rura-Polley, and Marton Marosszeky

2002 'Governmentality matters: Designing an alliance culture of inter-organizational collaboration for managing projects’. Organization Studies 23: 317-337.

Couchman, Paul K., and Liz Fulop

2002 'The meanings of risk and interorganizational collaboration' in Management and organization paradoxes. S.R. Clegg (ed), 40-64. Amsterdam: John Benjamins.

Daft, Richard L., and Karl E., Weick

1984 'Toward a model of organizations as interpretation systems'. Academy of Management Review 9: 284-295.

Delmar, Frédéric, and Scott A. Shane

2003 'Does business planning facilitate the development of new ventures?' Strategic Management Journal 24: 1165-1185.

De Rond, Mark, and Hamid Bouchikhi

2004 'On the dialectics of strategic alliances'. Organization Science 15: 56-69. 
Doz, Yves L.

1996 'The evolution of cooperation in strategic alliances: Initial conditions or learning processes?’ Strategic Management Journal 17: 55-83.

Eccles, Robert G., and Nitin Nohria

1992 Beyond the hype: Rediscovering the essence of management. Boston: HBS.

Elsbach, Kimberley D., Pamela S. Barr, and Andrew B. Hargadon

2005 'Identifying situated cognition in organizations'. Organization Science 16/4: 422-433.

Fiss, Peer C., and Edward J. Zajac

2006 'The symbolic management of strategic change: Sensegiving via framing and decoupling'. Forthcoming in Academy of Management Journal.

Giddens, Anthony

1984 The constitution of society. Berkeley: University of California Press.

Gioia, Dennis A., and Kumar Chittipeddi

1991 'Sensemaking and sensegiving in strategic change initiation'. Strategic Management Journal 12: 433-448.

Gomes-Casseres, Benjamin

1996 The alliance revolution. Cambridge: Harvard University Press.

Gouldner, Alvin W.

1954 Patterns of industrial bureaucracy. New York: Free Press.

Hage, Jerald, and Michael Aiken

1966 'Organizational alienation: A comparative analysis'. American Sociological Review 31: 497-507.

Hardy, Cynthia, Thomas B. Lawrence, and David Grant

2005 'Discourse and collaboration: The role of conversations and collective identity'. Academy of Management Review 30: 58-77.

Heide, Jan B.

2003 'Plural governance in industrial purchasing’. Journal of Marketing 67: 18-29.

Hill, Claire A.

2001 'A comment on language and norms in complex business contracting'. Chicago-Kent Law Review 77: 29-57.

Hill, Claire A., and Christopher King

2004 'How do German contracts do as much with fewer words?' Chicago-Kent Law Review 79: 889-926.

Hill, Robert C., and Michael Levenhagen

1995 'Metaphors and mental models: Sensemaking and sensegiving in innovative and entrepreneurial activities'. Journal of Management 21/6: 1057-1074. 
Hoang, Ha, and Frank T. Rothaermel

2005 'The effect of general and partner-specific alliance experience on joint R\&D project performance'. Academy of Management Journal 48: 332-345.

Jap, Sandy D.

2001 "Pie sharing” in complex collaboration contexts'. Journal of Marketing Research 38: 86-99.

Jap, Sandy D., and Shankar Ganesan

2000 'Control mechanisms and the relationship life cycle: Implications for safeguarding specific investments and developing commitment'. Journal of Marketing Research 37: 227245.

Kaghan, William N., and Michael D. Lounsbury

2006 'Articulation work, collective mind, and the institutional residue of organizational artifacts' Forthcoming in Artifacts and Organizations. A. Rafaelli, and M.G. Pratt (eds), Mahwah: Lawrence Erlbaum.

Kale, Prashant, Jeff H. Dyer, and Harbir Singh

2001 'Value creation and success in strategic alliances: Alliancing skills and the role of alliance structure and systems’. European Management Journal 19: 463-471.

Kaplan, Sarah, and Eric D. Beinhocker

2003 'The real value of strategic planning’. MIT Sloan Management Review 44: 71-76.

Katz, Daniel, and Robert L. Kahn

1966 The social psychology of organizations. New York: John Wiley.

Ketokivi, Mikko, and Xavier Catañer

2004 'Strategic planning as an integrative device'. Administrative Science Quarterly 49: 337365.

Kirsch, Laurie J.

2004 'Deploying common systems globally: The dynamics of control'. Information Systems Research 15/4: 374-395.

Klein Woolthuis, Rosalinde, Bas Hillebrand, and Bart Nooteboom

2005 'Trust, contract and relationship development'. Organization Studies 26/6: 813-840.

Kotabe, Masaaki, Xavier Martin, and Hiroshi Domoto

2003 'Gaining from vertical partnerships: Knowledge transfer, relationship duration, and supplier performance improvement in the U.S. and Japanese automotive industries'. Strategic Management Journal 24: 293-316.

Koza, Mitchell P., and Arie Y. Lewin

1998 ‘The co-evolution of strategic alliances’. Organization Science 9: 255-264.

Lane, Peter J., and Michael H. Lubatkin

1998 'Relative absorptive capacity and interorganizational learning'. Strategic Management Journal 19: 461-477. 
Lindenberg, Siegwart M.

2003 'The cognitive side of governance' in Research in the Sociology of Organizations. V. Buskens, W. Raub, and C. Snijders (eds), 20: 47-76. Oxford: JAI Press.

Lui, Steven S., and Hang-Yue Ngo

2004 'The role of trust and contractual safeguards on cooperation in non-equity alliances'. Journal of Management 30: 471-485.

Macneil, Ian R.

1980 The new social contract: An inquiry into modern contractual relations. London: Yale University Press.

Madhok, Anoop

2002 'Reassessing the fundamentals and beyond: Ronald Coase, the transaction cost and resource-based theories of the firm and the institutional structure of production'. Strategic Management Journal 23: 535-550.

Maitlis, Sally

2005 'The social processes of organizational sensemaking'. Academy of Management Journal 48: 21-49.

Mayer, Kyle J., and Nicholas S. Argyres

2004 'Learning to contract: Evidence from the personal computer industry'. Organization Science 15: 394-410.

McGinn, Kathleen L., and Angela Keros

2002 'Improvisation and the logic of exchange in socially embedded transactions'. Administrative Science Quarterly 47: 442-473.

McKinley, William, and Andreas G. Scherer

2000 'Some unanticipated consequences of organizational restructuring'. Academy of Management Review 25: 735-751.

Meindl, James R., Charles Stubbart, and Joseph F. Porac

1996 Cognition within and between organizations. Thousand Oaks: Sage.

Mills, Jean H.

2003 Making sense of organizational change. London: Routledge.

Mintzberg, Henry

1994 The rise and fall of strategic planning. Hemel Hempstead: Prentice Hall.

Mjoen, Hans, and Stephen Tallman

1997 'Control and performance in international joint ventures'. Organization Science 8: 257274.

Narayandas, Das, and V. Kasturi Rangan

2004 'Building and sustaining buyer-seller relationships in mature industrial markets'. Journal of Marketing 68: 63-77. 
Nellore, Rajesh

2001 'Validating specifications: Contract-based approach'. IEEE Transactions on engineering management 48/4: 491-504.

Ness, Håvard

2002 'Ex post contractual adjustments in dyadic interfirm relations'. Paper presented at the $12^{\text {th }}$ Nordic Workshop on Interorganizational Research. Kolding.

Nooteboom, Bart

1992 'Towards a dynamic theory of transactions'. Journal of Evolutionary Economics 2: 281299.

Obstfeld, David

2004 'Saying more and less of what we know: The social processes of knowledge creation, innovation and agency'. Unpublished manuscript.

Orlikowski, Wanda J., and JoAnne Yates

2002 'It's about time: Temporal structuring in organizations'. Organization Science 13/6: 684-700.

Ouchi, William G.

1979 'A conceptual framework for the design of organizational control mechanisms'. Management Science 25: 833-848.

Porac, Joseph F., Marc J. Ventresca, and Yuri Mishina

2002 'Interorganizational cognition and interpretation' in The Blackwell Companion to Organizations. J. Baum (ed), 579-598. Oxford: Blackwell Publishers.

Putnam, Linda L.

2003 'Dialectical tensions and rhetorical tropes in negotiations'. Organization Studies 25/1: 35-53.

Putnam, Linda L., and François Cooren

2004 'Alternative perspectives on the role of text and agency in constituting organizations'. Organization 11/3: 323-333.

Ranson, Stewart, Bob Hinings, and Royston Greenwood 1980 'The structuring of organizational structures'. Administrative Science Quarterly 25: 117.

Ring, Peter Smith

2000 'The three T's of alliance creation: Task, team and time'. European Management Journal 18: 153-162.

Ring, Peter Smith, and Gordon P. Rands

1989 'Sensemaking, understanding, and committing' in Research on the management of innovation: The Minnesota Studies. A.H. Van de Ven, H. Angle, and M.S. Poole (eds), 337366. New York: Ballinger/Harper Row. 
Ring, Peter Smith, and Andrew H. Van de Ven

1989 'Formal and informal dimensions of transactions' in Research on the management of innovation: The Minnesota Studies. A.H. Van de Ven, H. Angle, and M.S. Poole (eds), 171192. New York: Ballinger/Harper Row.

Ring, Peter Smith, and Andrew H. Van de Ven

1994 'Developmental processes of cooperative interorganizational relationships'. Academy of Management Review 19: 90-118.

Rothaermel, Frank T., and David L. Deeds

2004 'Exploration and exploitation alliances in biotechnology: A system of new product development'. Strategic Management Journal 25: 201-221.

Rouleau, Linda

2005 'Micro-practices of strategic sensemaking and sensegiving: How middle managers interpret and sell change every day'. Journal of Management Studies 42/7: 1413-1441.

Sampson, Rachelle C.

2003 ‘The role of lawyers in strategic alliances’. Case Western Law Review 53: 909-927.

Shankarmahesh, Malesh N., John B. Ford, and Michael S. LaTour

2004 'Determinants of satisfaction in sales negotiations with foreign buyers: Perceptions of US export executives’. International Marketing Review 21/4: 423-446.

Shenkar, Oded, and Yoram Zeira

1992 'Role conflict and role ambiguity of chief executive officers in international joint ventures’. Journal of International Business Studies 23: 55-75.

Simons, Robert

1995 Levers of control: How managers use innovative control systems to drive strategic renewal. Boston: HBS.

Sitkin, Sim. B., and Robert J. Bies

1993 'The legalistic organization: Definitions, dimensions, and dilemmas'. Organization Science 4/3: 345-351.

Sivadas, Eugene, and F. Robert Dwyer

2000 'An examination of organizational factors influencing new product success in internal and alliance-based processes’. Journal of Marketing 64: 31-49.

Snell, Robin S.

2002 'The learning organization, sensegiving and psychological contracts: A Hong Kong case'. Organization Studies 23/4: 549-569.

Sutcliffe, Kathleen M., and George P. Huber

1998 'Firm and industry as determinants of executive perceptions of the environment'. Strategic Management Journal 19: 793-807. 
Sutcliffe, Kathleen M., and Gerry M. McNamara

2001 'Controlling decision-making practice in organizations'. Organization Science 12/4: 484-501.

Sutcliffe, Kathleen M., and Klaus Weber

2003 'The high cost of accurate knowledge'. Harvard Business Review 81/5: 74-82.

Taylor, James R., and Daniel Robichaud

2004 'Finding the organization in the communication: Discourse as action and sensemaking'. Organization 11/3: 395-413.

Thomas, James B., and Linda K. Trevino

1993 'Information-processing in strategic alliance building: A multiple case approach'. Journal of Management Studies 30: 779-814.

Thomas, James B., Shawn M. Clark, and Dennis A. Gioia

1993 'Strategic sensemaking and organizational performance: Linkages among scanning, interpretation, action, and outcomes’. Academy of Management Journal 36: 239-270.

Turner, Jonathan H.

1987 'Toward a sociological theory of motivation’. American Sociological Review 52: 15-27.

Vaara, Eero

2003 'Post-acquisition integration as sensemaking: Glimpses of ambiguity, confusion, hypocrisy, and politicization'. Journal of Management Studies 40: 859-894.

Van de Ven, Andrew H., and M. Scott Poole

2005 'Alternative approaches for studying organizational change'. Organization Studies 26: $1377-1404$.

Volberda, Henk W.

1998 Building the flexible firm. Oxford: Oxford University Press.

Walton, Richard E., and Robert B. McKersie

1965 Behavioural theory of labour negotiations: An analysis of a social interaction system. New York: McGraw Hill.

Weick, Karl E.

1969/1979 The social psychology of organizing. Reading: Addison-Wesley.

Weick, Karl E.

1987 'Substitutes for strategy' in Competitive challenge. D.J. Teece (ed), 221-233. Cambridge: Ballinger.

Weick, Karl E.

1993 'The collapse of sensemaking in organizations: The Mann Gulch disaster'. Administrative Science Quarterly 38: 628-652.

Weick, Karl E.

1995 Sensemaking in organizations. London: Sage. 
Weick, Karl E.

2001 Making sense of the organization. Oxford: Blackwell.

Weick, Karl E.

2004 'Vita contemplativa. Mundane poetics: Searching for wisdom in organization studies'. Organization Studies 25: 653-668.

Weick, Karl E., and Reuben R. McDaniel Jr.

1989 'How professional organizations work: Implications for school organization and management' in Schooling for tomorrow. T.J. Sergiovanni, and J.H. Moore (eds), 330-355. Boston: Allyn and Bacon.

Weick, Karl E, and Roberts, Karlene H.

1993 'Collective mind and organizational reliability: The case of flight carrier operations on an aircraft carrier deck’. Administrative Science Quarterly 38: 357-381.

Weick, Karl E, and Kathleen M. Sutcliffe

2001 Managing the unexpected: Assuring high performance in an age of complexity. San Fransisco: Jossey-Bass.

Weick, Karl E., Kathleen M. Sutcliffe, and David Obstfeld

2005 'Organizing and the process of sensemaking'. Organization Science 16/4: 409-421.

White, Steven, and Steven S.-Y. Lui

2005 'Distinguishing costs of cooperation and control in alliances'. Strategic Management Journal, 26: 913-932.

Williamson, Oliver E.

1985 The economic institutions of capitalism. New York: Free Press.

Yakura, Elaine K.

2002 'Charting time: Timelines as temporal boundary objects'. Academy of Management Journal 45/5: 956-970.

Yu, Jisun, Rhonda Engelman, and Andrew H. Van de Ven

2005 'The integration journey: An attention-based view of the merger and acquisition integration process’. Organization Studies 26/10: 1501-1528.

Zollo, Maurizio, Jeff J. Reuer, and Harbir Singh

2002 'Interorganizational routines and performance in strategic alliances'. Organization Science 13: 701-713.

Zollo, Maurizio, and Sidney G. Winter

2002 'Deliberate learning and the evolution of dynamic capabilities'. Organization Science 13: 339-351.

Zollo, Maurizio, and Harbir Singh

2004 'Deliberate learning in corporate acquisitions: Post-acquisition strategies and integration capability in US bank mergers'. Strategic Management Journal 25:1233-1256. 


\section{Figure 1}

Relationships between formalization, mechanisms, sensemaking, and understanding in an interorganizational context

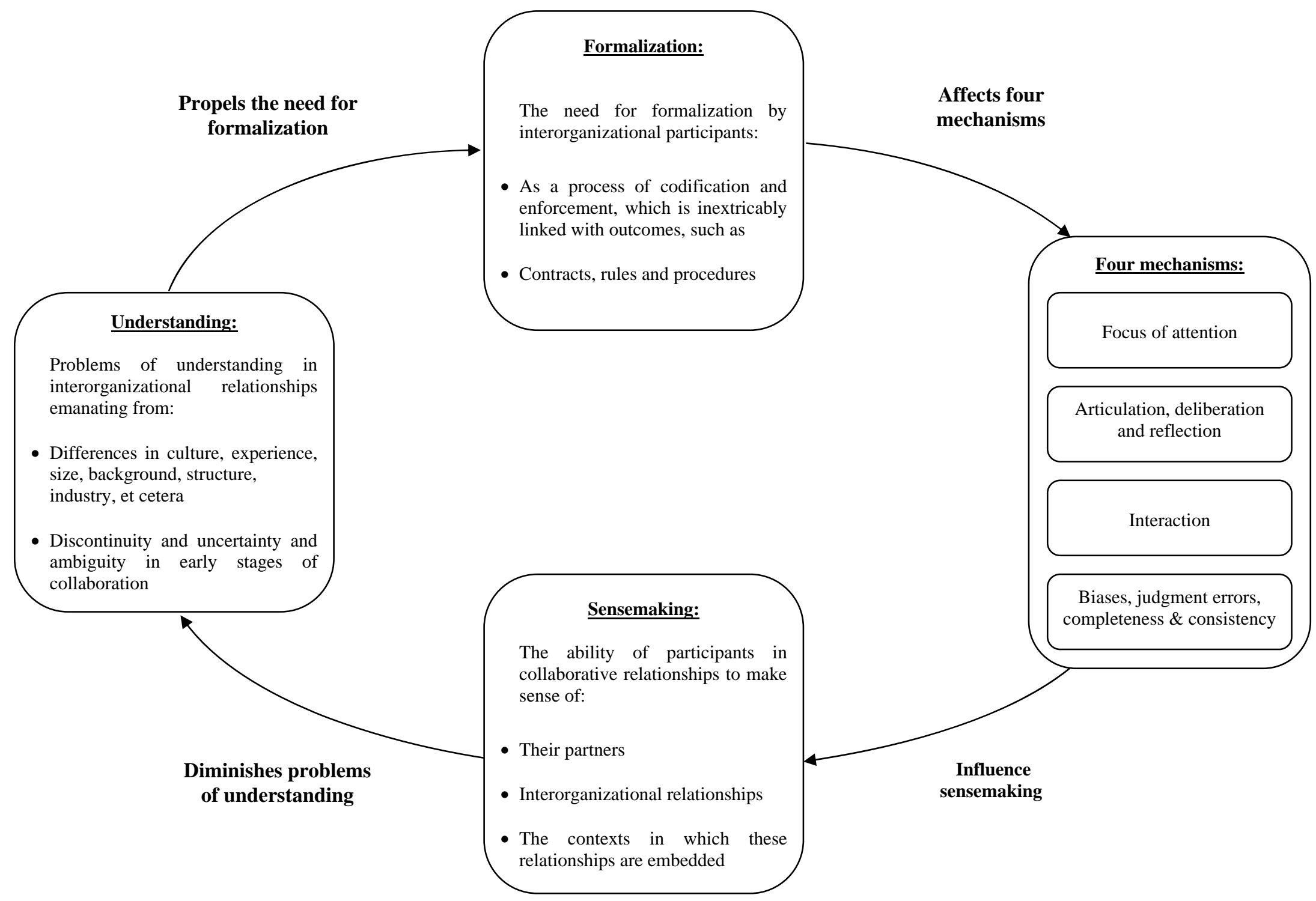




\section{Publications in the Report Series Research ${ }^{*}$ in Management}

\section{ERIM Research Program: "Strategy and Entrepreneurship"}

2006

Modeling Brand Extension as a Real Option: How Expectation, Competition and Financial Constraints Drive the Timing of Extensions

Lenny H. Pattikawa

ERS-2006-030-STR

http://hdl.handle.net/1765/7855

Coping with Problems of Understanding in Interorganizational Relationships: Using Formalization as a Means to make Sense Paul W.L. Vlaar, Frans A.J. Van den Bosch and Henk W. Volberda

ERS-2006-034-STR

On the Evolution of Trust, Distrust, and Formal Coordination and Control in Interorganizational Relationships: Towards an Integrative Framework

Paul W.L. Vlaar, Frans A.J. Van den Bosch and Henk W. Volberda ERS-2006-035-STR

Complex Incremental Product Innovation in Established Service Firms: A Micro Institutional Perspective Patrick A.M. Vermeulen, Frans A.J. Van den Bosch and Henk W. Volberda ERS-2006-037-STR

Exploratory Innovation, Exploitative Innovation, and Performance: Effects of Organizational Antecedents and Environmental Moderators

Justin J.P. Jansen, Frans A.J. Van den Bosch and Henk W. Volberda

ERS-2006-038-STR

\footnotetext{
A complete overview of the ERIM Report Series Research in Management: https://ep.eur.nl/handle/1765/1

ERIM Research Programs:

LIS Business Processes, Logistics and Information Systems

ORG Organizing for Performance

MKT Marketing

F\&A Finance and Accounting

STR Strategy and Entrepreneurship
} 